\title{
Review of Hydrogen Standards for China
}

\author{
Yanmei Yang*, Geng Wang, Sinan Zhang, Lan Zhang, and Ling Lin \\ China National Institute of Standardization, Beijing, China
}

\begin{abstract}
Standards are essential to establish a market-receptive and safe environment for commercial hydrogen equipment and systems. A review of ISO, IEC and Chinese national hydrogen standards is presented in this paper. China has a larger number of hydrogen national standards than ISO and IEC, involving terminology, hydrogen fuel quality, hydrogen safety, construction, production and purification, storage, transportation and fuelling, applications, and testing. ISO hydrogen standards are mainly specialized in hydrogen fuel quality, safety, production, hydrogen fuelling station, and testing. IEC hydrogen standards are mainly specialized in fuel cell safety, applications and testing. Hydrogen standard system is now imbalanced and insufficient for China. We should pay much more attention on drafting standards for hydrogen production, storage, transportation and fuelling.
\end{abstract}

\section{Introduction}

Emissions from the energy and transport sectors are exacerbating climate change and reducing air quality. Hydrogen is one of only a few potential near-zero emission energy carrier, which has the potential to play a significant role in reducing GHG emission and improving air quality ${ }^{[1,2]}$. Hydrogen has garnered interest in recent years in applications of transportation and power, for example hydrogen fuel cell passenger cars, buses, trucks, trains, forklifts, ships, scooters, and stationary and portable fuel cell power systems ${ }^{[3]}$.

Hydrogen fuel cell vehicles have been previously demonstrated in Olympic Games, World Expo, and Asian Games in China. Since 2017, hydrogen industry is booming in China. By the end of 2018, more than 25 cities have announced to support the deployment of hydrogen industry. The cumulative sales number of hydrogen fuel cell vehicles reached 3428. About 23 hydrogen fuelling stations are in operation. More 40 hydrogen fuelling stations are in construction and planning. Hydrogen fuel cell buses and trucks are in demonstration in Beijing, Foshan, Shanghai, Zhenghou, Yanchen, Yunfu, Zhangjiakou, etc ${ }^{[4,5]}$.

Standards provide technical definitions, guidelines, and instructions for design, manufacture, and testing. Standards also set minimum component or performance requirements. Standards are essential to establish a market-receptive and safe environment for commercial hydrogen equipment and systems.

International Organization for Standardization (ISO) and International Electrotechnical Commission (IEC) are the two key international standard development organizations. In China, Standardization Administration of the P. R. C. (SAC) undertakes unified management, supervision and overall coordination of standardization work in China. A review ISO, IEC and Chinese national hydrogen standards is presented and discussed in this paper. Organization of this paper is as follows:

In session 2, hydrogen standard framework and technical committees are introduced.

In session 3, details and distribution of hydrogen standards for China are described and discussed.

In session 4, we summarize the main conclusions and provide some advices for hydrogen standardization work.

\section{Hydrogen standard framework}

\subsection{National technical committees}

Standard Technical committees are unincorporated technical organizations devoting to draft national standards in specific fields. There are four main national technical committees engaging in drafting national hydrogen standards. National Technical Committee of Hydrogen Energy (SAC/TC 309) is specialized in national standards on hydrogen production, storage, transportation and fuelling, application, testing, safety, etc. National Technical Committee of Fuel Cell and Flow Battery (SAC/TC 342) is specialized in national standards on fuel cell terminology, stacks, and applications. Subcommittee of Electric Vehicles of National Technical Committee of Road Vehicles (SAC/TC 114/SC 27) is specialized in national standards on fuel cell vehicles. Subcommittee of High Pressure Vehicle Fuel Tanks of National Technical Committee of Gas Cylinders (SAC/TC 31/SC 8) is specialized in national standards on composite material cylinders including high pressure hydrogen cylinders for vehicles. National Technical Committees of Gases, Work Safety, Metallic and Non-metallic Coatings also devote to draft hydrogen related national standards.

\footnotetext{
* Corresponding author: yangym11thu@163.com
} 


\subsection{ISO technical committees}

Technical Committee of Hydrogen Technologies (ISO/TC 197) is specialized in standardization in the field of systems and devices for the production, storage, transport, measurement and use of hydrogen. Subcommittee of Electrically Propelled Vehicles of Road Vehicles (ISO/TC 22/SC 37) is specialized in aspects of electrically propelled road vehicles, electric propulsion systems, related components and their vehicle integration.

\subsection{IEC technical committees}

Technical Committee of Fuel Cell Technologies (IEC/TC 105) is the main technical committee involving in drafting IEC hydrogen standards. IEC/TC 105 is specialized to develop standards of fuel cell technologies for all fuel cell (FC) types and various associated applications, including stationary FC power systems for distributed power generators and combined heat and power systems, FCs for transportation, auxiliary power units, portable FC power systems, micro $\mathrm{FC}$ power systems, etc.

\subsection{Hydrogen standard framework for China}

Hydrogen industry chain is complicated, involving production, storage, transportation, fuelling station, application, etc. Hydrogen standard framework is the guidance and base for hydrogen standardization work. In 2010, SAC/TC 309 established the hydrogen standard framework and prepared lists of standards in being and in planning for China.

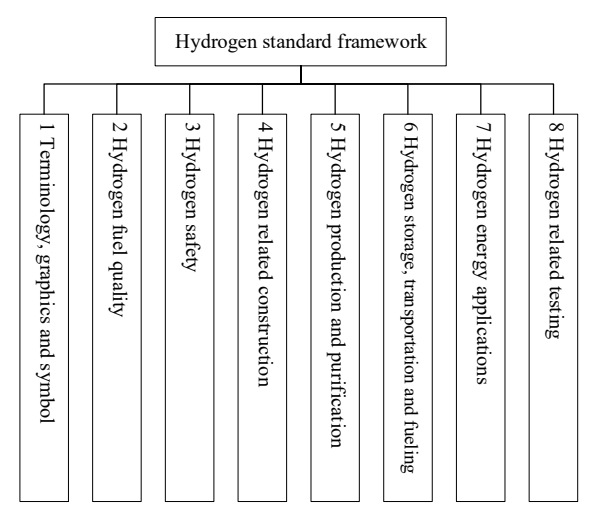

Fig. 1. Hydrogen standard framework for China ${ }^{[6]}$

As is shown in Figure 1, hydrogen standard framework consists of eight parts, including terminology, graphics and symbols; hydrogen fuel quality; safety; construction; production and purification; storage, transportation and fuelling; applications; and testing ${ }^{[7]}$.

a) Terminology, graphics and symbols: This part includes standards of glossary, classification, symbols, naming specification, etc.

b) Hydrogen fuel quality: This part includes standards of hydrogen specification for gaseous hydrogen, liquid hydrogen, HCNG, etc. c) Hydrogen safety: This part includes standards of safety in production, storage, transportation, fuelling, application, operation, etc.

d) Hydrogen related construction: This part includes standards of design, construction, installation, and verification, etc.

e) Hydrogen production: This part includes standards of various hydrogen production methods, including water electrolysis, purification of industrial gas, methanol reforming, steam reforming of natural gas, coal gasification, etc.

f) Hydrogen storage, transportation and fuelling: This part includes standards of storage and transportation for gaseous hydrogen, liquid hydrogen, and hydrogen absorbed in reversible metal hydride. It also includes standards of hydrogen fuelling stations and its components.

g) Hydrogen applications: This part includes standards for various applications of fuel cells, not only transportation, but also power generation, combined heat and power systems, etc.

h) Testing: This part includes testing standards for hydrogen production, storage tanks and materials, performance of applications, safety, etc.

\section{Standards}

Figure 2 shows the number of existing and effective national, ISO and IEC standards for hydrogen. China now has 93 national standards for hydrogen infrastructure and applications, which is much more than the number of ISO and IEC standards. The number of ISO hydrogen standards is 28 . The number of IEC fuel cell standards is 17 .

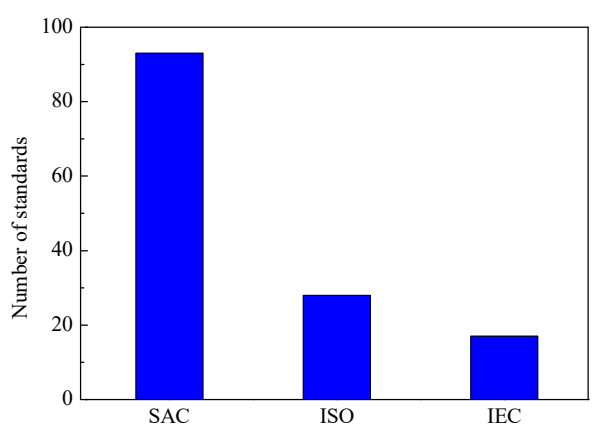

Fig. 2. Number of national, ISO and IEC hydrogen standards

\subsection{ISO standards}

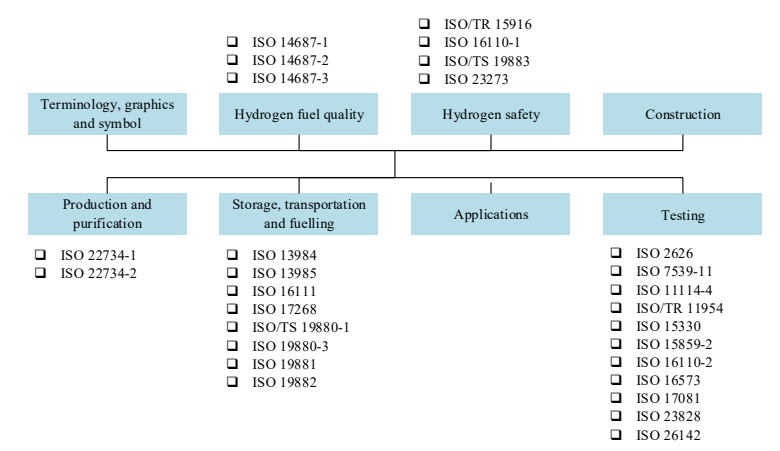

Fig. 3. Distribution of ISO hydrogen standards 
Figure 3 shows the distribution of ISO hydrogen standards according to the hydrogen standard framework for China. Number of testing standards is more than others. There is no ISO hydrogen standards of terminology, construction and applications. Details are as follows:

a) Hydrogen fuel quality: There are three ISO standards of hydrogen fuel specification for different applications.

口 ISO 14687-1:1999 Hydrogen fuel -- Product specification -- Part 1: All applications except proton exchange membrane (PEM) fuel cell for road vehicles (including two technical corrigendum)

$\square$ ISO 14687-2:2012 Hydrogen fuel -- Product specification -- Part 2: Proton exchange membrane (PEM) fuel cell applications for road vehicles

$\square$ ISO 14683-3:2014 Hydrogen fuel -- Product specification -- Part 3: Proton exchange membrane (PEM) fuel cell applications for stationary appliances

b) Hydrogen safety: There are four standards of hydrogen safety. One of them is for safety of hydrogen system. Two of them are for safety of hydrogen production, including water electrolysis and PSA. The other one of them is for safety of fuel cell road vehicles.

$\square$ ISO/TR 15916:2015 Basic considerations for the safety of hydrogen systems

$\square$ ISO 16110-1:2017 Hydrogen generators using fuel processing technologies -- Part 1: Safety

$\square$ ISO/TS 19883:2017 Safety of pressure swing adsorption systems for hydrogen separation and purification

口 ISO 23273:2013 Fuel cell road vehicles -- Safety specifications -- Protection against hydrogen hazards for vehicles fuelled with compressed hydrogen

c) Hydrogen production and purification: There are two standards for hydrogen production by water electrolysis.

$\square$ ISO 22734-1:2008 Hydrogen generators using water electrolysis process -- Part 1: Industrial and commercial applications

$\square$ ISO 22734-2:2011 Hydrogen generators using water electrolysis process -- Part 2: Residential applications

d) Hydrogen storage, transportation and fuelling:

There are four standards for hydrogen storage.

$\square$ ISO 13985:2006 Liquid hydrogen -- Land vehicle fuel tanks

口 ISO 16111:2018 Transportable gas storage devices -- Hydrogen absorbed in reversible metal hydride

口 ISO 19881:2018 Gaseous hydrogen -- Land vehicle fuel containers

口 ISO 19882:2018 Gaseous hydrogen -- Thermally activated pressure relief devices for compressed hydrogen vehicle fuel containers

There are four standard for hydrogen fuelling.

口 ISO 13984:1999 Liquid hydrogen -- Land vehicle fuelling system interface

$\square$ ISO 17268:2012 Gaseous hydrogen land vehicle refuelling connection devices $\square$ ISO/TS 19880-1:2016 Gaseous hydrogen -Fuelling stations -- Part 1: General requirements

$\square$ ISO 19880-3:2018 Gaseous hydrogen -- Fuelling stations -- Part 3: Valves

e) Testing: There are eleven standards for testing. Six of them are about hydrogen embrittlement.

口 ISO 2626:1973 Copper -- Hydrogen embrittlement test

$\square$ ISO 7539-11:2013 Corrosion of metals and alloys - Stress corrosion testing -- Part 11: Guidelines for testing the resistance of metals and alloys to hydrogen embrittlement and hydrogen-assisted cracking

口 ISO 11114-4:2017 Transportable gas cylinders -Compatibility of cylinder and valve materials with gas contents -- Part 4: Test methods for selecting steels resistant to hydrogen embrittlement

$\square$ ISO 15330:1999 Fasteners -- Preloading test for the detection of hydrogen embrittlement -- Parallel bearing surface method

ISO 16573:2015 Steel -- Measurement method for the evaluation of hydrogen embrittlement resistance of high strength steels

口 ISO 17081:2014 Method of measurement of hydrogen permeation and determination of hydrogen uptake and transport in metals by an electrochemical technique

Three of them are for testing of applications.

$\square$ ISO/TR 11954:2008 Fuel cell road vehicles -Maximum speed measurement

口 ISO 15859-2:2004 Space systems -- Fluid characteristics, sampling and test methods -- Part 2: Hydrogen.

口 ISO 23828:2013 Fuel cell road vehicles -- Energy consumption measurement -- Vehicles fuelled with compressed hydrogen.

One of them is for testing of hydrogen production by water electrolysis.

$\square$ ISO 16110-2:2010 Hydrogen generators using fuel processing technologies -- Part 2: Test methods for performance

Another one of them is for hydrogen detection.

口 ISO 26142:2010 Hydrogen detection apparatus -Stationary applications

\subsection{IEC standards}

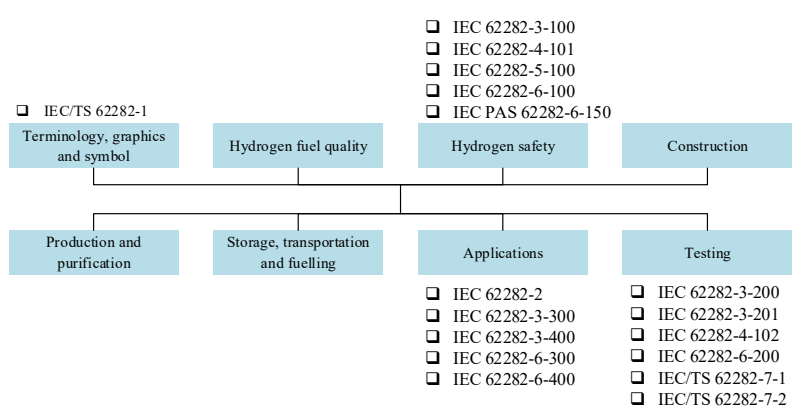

Fig. 4. Distribution of IEC hydrogen standards

Figure 4 shows the distribution of IEC hydrogen standards according to the hydrogen standard framework 
for China. IEC standards are for fuel cells and its various applications. Details are as follows:

a) Terminology, graphics and symbols: There is one standard of terminology.

$\square$ IEC/TS 62282-1:2013 Fuel cell technologies - Part 1: Terminology.

b) Hydrogen safety: There are five standards for safety of fuel cell applications.

$\square$ IEC 62282-3-100:2019 Fuel cell technologies Part 3-100: Stationary fuel cell power systems Safety

口 IEC 62282-4-101:2014 Fuel cell technologies Part 4-101: Fuel cell power systems for propulsion other than road vehicles and auxiliary power units (APU) - Safety of electrically powered industrial trucks

$\square$ IEC 62282-5-100:2018 Fuel cell technologies Part 5-100: Portable fuel cell power systems Safety

口 IEC 62282-6-100:2010 Fuel cell technologies Part 6-100: Micro fuel cell power systems - Safety

$\square$ IEC PAS 62282-6-150:2011 Fuel cell technologies - Part 6-150: Micro fuel cell power systems Safety - Water reactive (UN Devision 4.3) compounds in indirect PEM fuel cells.

c) Hydrogen applications: There are five standards for fuel cell applications. Two of them are about stationary fuel cell power systems. Two of them are about micro fuel cell power systems.

口 IEC 62282-2:2012 Fuel cell technologies - Part 2: Fuel cell modules

口 IEC 62282-3-300:2012 Fuel cell technologies Part 3-300: Stationary fuel cell power systems Installation

口 IEC 62282-3-400:2016 Fuel cell technologies Part 3-400: Stationary fuel cell power systems Small stationary fuel cell power system with combined heat and power output

口 IEC 62282-6-300:2012 Fuel cell technologies Part 6-300: Micro fuel cell power systems - Fuel cartridge interchangeability

$\square$ IEC 62282-6-400:2019 Fuel cell technologies Part 6-400: Micro fuel cell power systems - Power and data interchangeability

d) Testing: There are six standards for testing of fuel cell applications.

口 IEC 62282-3-200:2015 Fuel cell technologies Part 3-200: Stationary fuel cell power systems Performance test methods

口 IEC 62282-3-201:2017 Fuel cell technologies Part 3-201: Stationary fuel cell power systems Performance test methods for small fuel cell power systems

口 IEC 62282-4-102:2017 Fuel cell technologies Part 4-102: Fuel cell power systems for industrial electric trucks - Performance test methods

$\square$ IEC 62282-6-200:2016 Fuel cell technologies Part 6-200: Micro fuel cell power systems Performance test methods

口 IEC/TS 62282-7-1:2017 Fuel cell technologies Part 7-1: Test methods - Single cell performance tests for polymer electrolyte fuel cells (PEFC) $\square$ IEC/TS 62282-7-2:2014 Fuel cell technologies Part 7-2: Test methods - Single cell and stack performance tests for solid oxide fuel cells (SOFC)

\subsection{National standards}

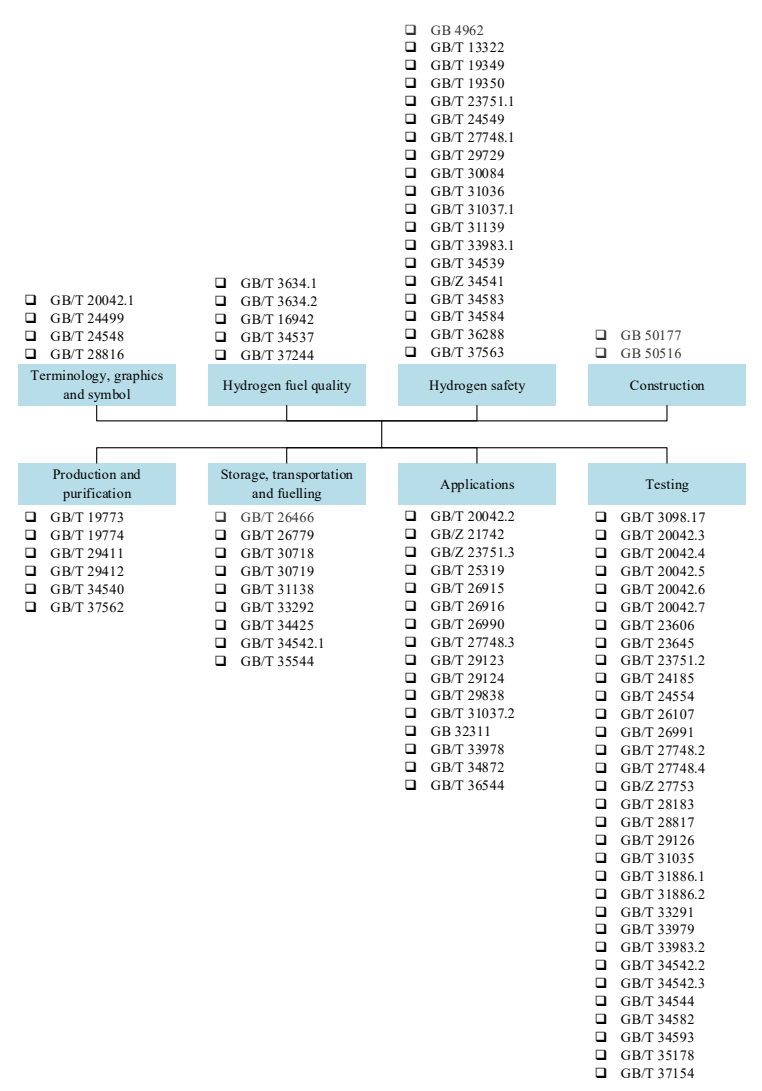

Fig. 5. Distribution of national hydrogen standards

Figure 5 shows the distribution of national hydrogen standards. Numbers of standards for hydrogen safety, applications and testing are more than that of others. Details are as follows:

a) Terminology, graphics and symbols: There are four terminology standards, including: glossary for hydrogen, hydrogen energy and hydrogen energy system, terminology of PEM fuel cell, terminology of fuel cell, and terminology of fuel cell vehicles.

b) Hydrogen fuel quality: There are five standards for hydrogen specification. GB/T 3634.1 is for industrial hydrogen. GB/T 3634.2 is for pure, high pure and ultrapure hydrogen. GB/T 16942 is for hydrogen for electronic industry. GB/T 34537 is for hydrogen and compressed natural gas blends. GB/T 37244 is the specification of hydrogen fuel for proton exchange membrane fuel cell vehicles.

c) Hydrogen safety: There are 19 standards for hydrogen safety. GB 4962-2008 and GB/T 297292013 are for safety of hydrogen systems. GB/T 13322-1991, GB/T 19349-2012 and GB/T 193502012 are for safety of materials. GB/T 34539-2017 and GB/T 37563-2019 are for safety of water electrolysis systems. GB/T 31139-2014, GB/Z 345412017, GB/T 34583-2017, GB/T 34584-2017 and GB/T 36288-2018 are for safety of hydrogen storage 
and fuelling. GB/T 23751.1-2009, GB/T 24549-2009, GB/T 27748.1-2017, GB/T 30084-2013, GB/T 31036-2014, GB/T 31037.1-2014 and GB/T 33983.12017 are for safety of fuel cells and fuel applications.

d) Hydrogen construction: GB 50177-2005 and GB 50516-2010 are two mandatory national standard of hydrogen fuelling station, involving requirements of design, layout, building structure, electrical and instrument control, lightning protection, water supply and drainage, firefighting, heating and ventilation, hydrogen pipeline, etc.

e) Hydrogen production and purification: There are six standards for hydrogen production and purification. GB/T 19774-2005, GB/T 29411-2012, $\mathrm{GB} / \mathrm{T}$ 29412-2012 and $\mathrm{GB} / \mathrm{T}$ 37562-2019 are for water electrolysis system. GB/T 19773-2005 and GB/T 29412-2012 are for hydrogen purification system on pressure swing adsorption. GB/T 345402017 is for hydrogen production by methanol reforming and pressure swing adsorption.

f) Hydrogen storage, transportation and fuelling: There are nine standards for hydrogen storage and fuelling. GB/T 34542.1-2017 is the general requirements for gaseous hydrogen storage and transportation systems. GB/T 26466-2011, GB/T 33292-2016 and GB/T 35544-2017 are for hydrogen storage. GB/T 30718-2014, GB/T 30719-2014, GB/T $31138-2014$, GB/T 26779-2011 and GB/T 344252017 are for hydrogen fuelling.

g) Hydrogen applications: There are sixteen standards for hydrogen and fuel cell applications. GB/T 20042.2-2008, GB/T 29838-2013 and GB/T 348722017 are for fuel cells. GB/Z 21742-2008, GB/Z 23751.3-2013, GB/T 27748.3-2017 and GB/T 365442018 are for fuel cell power systems. GB/T 253192010, GB/T 26990-2011, GB/T 29123-2012, GB/T 29124-2012, GB/T 31037.2-2014 and GB/T 339782017 are for fuel cell vehicles. GB/T 26915-2011, GB/T 26916-2011 and GB 32311-2015 are for other use of hydrogen energy.

h) Testing: There are thirty two standards for testing. GB/T 23606-2009, GB/T 24185-2009, GB/T 261072010, GB/T 3098.17-2000, GB/T 34542.2-2018 and $\mathrm{GB} / \mathrm{T}$ 34542.3-2018 are the testing standards for materials. GB/T 33291-2016 is the measurement method of pressure-composition-temperature for reversible hydrogen absorption and desorption of hydrides. GB/T 23645-2009, GB/T 24554-2009, GB/T 26991-2011, GB/T 28183-2011, GB/T 291262012, GB/T 34544-2017, GB/T 34593-2017, GB/T 35178-2017 and $\mathrm{GB} / \mathrm{T}$ 37154-2018 are testing standards for fuel cell vehicles. GB/T 20042.3-2009, GB/T 20042.4-2009, GB/T 20042.5-2009, GB/T 20042.6-2011, GB/T 20042.7-2014, GB/Z 277532011, GB/T 28817-2012, GB/T 31035-2014, GB/T 31886.1-2015, GB/T 31886.2-2015, GB/T 339792017, GB/T 33983.2-2017 and GB/T 34582-2017 are testing standards for fuel cell and fuel cell systems. GB/T 23751.2-2017, GB/T 27748.2-2013 and GB/T
27748.4-2017 are for fuel cell power generation systems.

\subsection{Summary}

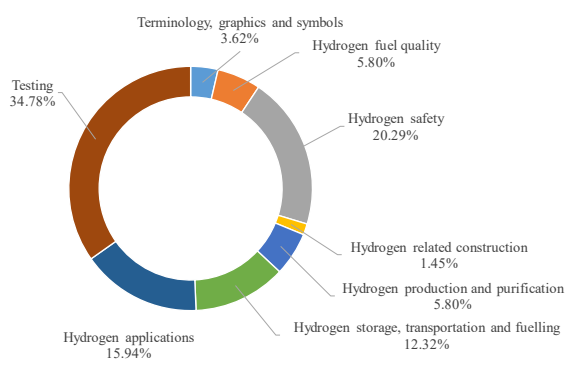

Fig. 6. Distribution of ISO, IEC and national hydrogen standards

Figure 6 shows the distribution of ISO, IEC and national hydrogen standard. Amount of testing standards are more than the others. Amount of standards for hydrogen construction, production and purification, storage, transportation and fuelling are not adequate.

\section{Conclusions}

A review of ISO, IEC and Chinese national hydrogen standards is presented in this paper. Based on analysis and comparison, concluding remarks are as follows:

(1) China has a larger number of hydrogen national standards than ISO and IEC, involving terminology, hydrogen fuel quality, hydrogen safety, construction, production and purification, storage, transportation and fuelling, applications, and testing.

(2) ISO hydrogen standards are mainly specialized in hydrogen fuel quality, safety, production, hydrogen fuelling station, and testing.

(3) IEC hydrogen standards are mainly specialized in fuel cell safety, applications and testing.

(4) Hydrogen standard system is imbalanced and insufficient for China. We should pay much more attention on drafting standards for hydrogen production, storage, transportation and fuelling.

\section{References}

1. Hydrogen Council. Hydrogen scaling up - a sustainable pathway for the global energy transition (2017)

2. J. D. Holladay, J. Hu, D. L. King, Y. Wang, Catalysis Today 139, 17 (2009)

3. E4tech. The fuel cell industry reviews (2018)

4. China National Instititue of Standardizaiton. Blue book for infrastructure development of hydrogen industry in China (China Quality and Standard Press, 2018)

5. China Hydrogen Alliance. White book on hydrogen energy and fuel cell industry in China (2019)

6. G. Wang, A. Zuo, A. Li, L. Chen, China Standarization 4, 4 (2010) 
7. G. Wang, J. Zheng, Standard system and strategy for hydrogen energy technologies (Chemical Industry Press, 2012) 